\title{
Przywódca-budowniczy sanktuarium Izraela według narracji starotestamentalnej
}

Tekst Starego Testamentu w wielu miejscach odnosi się do budowlanej działalności człowieka. Notuje ją już pierwsza księga biblijna (Rdz 4, 17b; 6, 14-16. 22; 8, 20), a obszerna narracja Księgi Wyjścia (Wj 36-38) podejmuje szczegółowo problematykę robót rzemieślniczo-budowlanych. Działalność budowlana skupia się na takich (według gradacji wielkości) obiektach jak miasto (np. Wj 1, 11b), jego fortyfikacje (np. 2 Sm 5, 9b; 2 Krn 26, 9), świątynia (np. $1 \mathrm{Krl}$ 9, 10), pałac (tamże), Przybytek (np. Wj 40, 17-19), dom (np. Rdz 33, 17). Ta działalność budowlana była skutkiem rozwoju cywilizacyjnego ludów, których dzieje podejmowała narracja biblijna. Przejście z wędrownego na osiadły tryb życia stymulowało budowę miast z takimi obiektami jak świątynie, budynki urzędowe, fortyfikacje. Wzrost liczby ludności oraz postęp techniki i technologii budowlanej pociągał za sobą zarówno przyrost (tzw. współcześnie) „masy mieszkaniowej”, jak i zmianę standardów wykonawczych. Zastąpienie struktury plemiennej hierarchiczną stymulowało rozwój ekskluzywnych budowli kubaturowych: rezydencji, pałaców.

Przedstawiona na kartach Starego Testamentu działalność budowlana to nie tylko wznoszenie nowych obiektów, lecz także remont lub odbudowa istniejących, jeśli uległy destrukcji wskutek działania czynników atmosferycznych (np. Syr 50, 1) lub katastroficznych (trzęsienia ziemi, zniszczenia wojenne, np. Neh 3; Syr 49,13). Wielokrotnie działalność ta była podejmowana przez człowieka w wyniku Bożej inspiracji - tak powstała arka ( $R d z 6,14-16.22)$, ołtarz (np. 2 Sm 24, 18n. 25a), a także sanktuarium Izraela. Tylko tę ostatnią spośród wymienionych sytuację 
obrano za przedmiot analizy, w wyniku której nakreślona zostanie sylwetka starotestamentalnego budowniczego sanktuarium Izraela ${ }^{1}$.

Należy mieć jednak na względzie, iż działalność budowlana przypisana budowniczemu sanktuarium Izraela nie odnosi się do jego bezpośrednich czynności budowlanych, lecz do działań sprawczych. Taka zastosowana w Biblii konstrukcja literacka odpowiada ówczesnemu kanonowi w kręgu kulturowym Bliskiego Wschodu; narracja literacka eksponuje funkcję władcy w procesie budowlanym oraz tytułuje go budowniczym monumentalnego obiektu.Jako przykłady można wymienić inskrypcje Nabonida oraz Warad-Sina².

Każdy starotestamentalny budowniczy sanktuarium Izraela pozostaje w szczególnej relacji do Boga, którą znamionuje: posłuszeństwo, zawierzenie oraz pietyzm. Wykazuje ponadto walory osobowe niezbędne przy wielkich przedsięwzięciach budowlanych: roztropność, solidność, męstwo. Owe znamienne cechy budowniczych sanktuariów Izraela przedstawiono poniżej w syntetycznym omówieniu.

\section{Sylwetka starotestamentalnego}

budowniczego sanktuarium Izraela

Budowniczego dla każdego starotestamentalnego sanktuarium Izraela wybiera sam Bóg, w szczególności do budowy Przybytku (Wj 25, 8n), Pierwszej Świątyni (1 Krn 17, 12; 22, 9n; 28, 5n), Drugiej Świątyni (Ag 2, 2-4). Budowniczym sanktuarium Izraela ustanawia Bóg każdorazowo zwierzchnika wspólnoty: rodowej - Mojżesz, narodowej - Dawid i Salomon, społecznej - Zorobabel. Owego wybrańca wyróżniają następujące cechy:

\section{Posłuszeństwo Bogu}

Mojżesz podejmuje nakaz Boga dotyczący daniny na budowę Przybytku (Wj 25, 1nn) i ogłasza go wspólnocie rodów Izraela (Wj 35, 4nn).

${ }^{1}$ Tak rozbudowane określenie (tytuł) owego budowniczego zastosowano tutaj celem pominięcia Heroda Wielkiego.

${ }^{2}$ Transliterację i transkrypcję inskrypcji Nabonida oraz Warad-Sina zamieszczono w: A. T. Clay, Miscellaneous Inscriptions in the Yale Babylonian Collection, Yale 1915 (Yale Oriental Series. Babylonian Texts, 1). 
Dawid posłuszny woli Boga (2 Sm 7, 12n) zrezygnował z budowania świątyni w Jerozolimie, natomiast podjął wielorakie przygotowania dla celu tej budowy (1 Krn 22, 5), następnie „zawołał syna swego, Salomona, i nakazał mu zbudować świątynię dla Pana, Boga Izraela" (1 Krn 22, 6)3.

Zorobabel podejmuje nakaz Boga przekazany przez proroka Aggeusza (Ag 1,1-8; Ezd 5, 1 wymienia również proroka Zachariasza) i wraz $\mathrm{z}$ arcykapłanem Jozuem przystępują „do rozpoczęcia budowy domu Bożego [Drugiej Świątyni] w Jerozolimie" (Ezd 5, 2b).

\section{Zawierzenie Bogu}

W narracji biblijnej cecha ta jest wielokrotnie poświadczana w różnych sytuacjach z udziałem Mojżesza (np. Wj 4, 19n; 7, 1nn; Lb 16, 4. 8; 16-26). Stanowi to istotny argument dla przypisania jej temu przywódcy również w zakresie oraz czasie pełnienia funkcji budowniczego Przybytku.

W przypadku Dawida jego zawierzenie obietnicy Boga wyraża kilka fragmentów zapisu biblijnego:

- 1 Krn 22, 13b: ufny Bożej obietnicy (2 Sm 7, 12n; 1 Krn 22, 8-10) zachęca Salomona do odwagi w realizacji monumentalnego przedsięwzięcia budowlanego - Świątyni Jerozolimskiej;

- 1 Krn 22,14: przygotowuje dla zapowiedzianej przez Boga inwestycji budulec oraz kruszce;

- 1 Krn 28, 11. 19n: ufny Bożej obietnicy (2 Sm 7, 12n; 1 Krn 22, 8-10) przekazuje swemu następcy Salomonowi plany budowlane świątyni.

Zapowiedź budowy świątyni ogłoszona z woli Boga Dawidowi stanowi zasadniczy argument przedstawiony przez Salomona Hiramowi, królowi Tyru, gdy zwraca się z prośbą o dostawę materiałów oraz kooperację na rzecz budowy świątyni w Jerozolimie: „Wtedy Salomon przesłał Hiramowi takie słowa: [...] zamierzam budować świątynię Imieniu Pana, Boga mego, stosownie do tego, co Pan rzekł Dawidowi, memu ojcu: «Twój syn, którego ci dam jako następcę na twoim tronie, on właśnie będzie budował świątynię dla mego Imienia». [...] Teraz więc każ naścinać mi cedrów z Libanu" (1 Krl 5, 16-20a). Słowa te wskazują zawierzenie Bożej obietnicy przez młodego władcę Izraela.

${ }^{3}$ Cytaty biblijne za: Pismo Święte Starego i Nowego Testamentu w przekładzie zjęzyków oryginalnych ze wstępami i komentarzami [Biblia Tysiaclecia], oprac. zespół biblistów polskich z inicjatywy benedyktynów tynieckich, Poznań 1984; Ezd 5, 2 b z uzupełnieniem autora. 
Budowniczy Drugiej Świątyni Jerozolimskiej Zorobabel zawierzył proroctwom ogłoszonym przez Aggeusza $(\mathrm{Ag} 2,4)$ oraz Zachariasza (Za 4, 6-9) i pomimo zakazu Artakserksesa (Ezd 4, 17-22), władcy babilońskiego sprawującego zwierzchnictwo polityczne nad Jerozolimą, kontynuował (Ezd 4, 24-5, 2) wstrzymane dekretem tegoż władcy prace przy odbudowie Pierwszej Świątyni.

\section{Pietyzm (religijność)}

Ta cecha przywódcy-budowniczego przejawia się w postawie czci wobec Boga, co odnośnie do Mojżesza wyraża np. Wj 34, 8, a odnośnie do Dawida np. 1 Krn 29, 10-20a.

Pietyzm wybrańców-budowniczych znajduje wyraz również w sprawowaniu obrzędów religijnych wieńczących ukończenie budowy sanktuarium:

- Mojżesz namaszcza Przybytek wraz z wyposażeniem i w ten sposób dokonuje nakazanego przez Boga poświęcenia (Wj 40, 9-11. 16);

- Salomon po przeniesieniu Arki Pańskiej do świątyni przeznacza na ofiarę wielką liczbę zwierząt; w akcie poświęcenia świątyni i dziedzińca składa ofiarę biesiadną oraz całopalną i pokarmową, następnie uczestniczy w obchodach święta z okazji ukończenia budowy (1 Krl 8, 62-65);

- Zorobabel składa Bogu ofiarę całopalną po wzniesieniu ołtarza całopalenia na dziedzińcu odbudowywanej świątyni; zapis Za 4, 8 oraz Ag 2, 2nn pozwala zasadnie domniemywać, iż ten przywódca społeczności repatriantów izraelskich uczestniczył w ceremonii poświęcenia (opisanej w Ezd 6, 16n) Drugiej Świątyni, a także sprawowanych wówczas obrzędach ofiarniczych.

\section{Roztropność}

Tę cechę wykazuje Mojżesz, usilnie zabiegając o osobiste, nieustanne uczestnictwo Boga w etosie Wyjścia (Wj 33,16n). Przejawia ją również poprzez zlecenie wykonawstwa Przybytku oraz wyposażenia wyłącznie grupie wyspecjalizowanych rzemieślników, których wyróżnia osobiste zaangażowanie w to dzieło: „Następnie wezwał Mojżesz Besaleela, Oholiaba i wszystkich biegłych w rzemiośle, których serce obdarzył Pan mądrością, wszystkich tych, których serce skłaniało, aby pójść do pracy nad wykonaniem dzieła" (Wj 36, 2). 
Dawid jest świadom, iż ten przymiot winien cechować budowniczego Świątyni Jerozolimskiej (1 Krn 22, 11n). Wykazał on roztropność, dokonując właściwej oceny wydatków oraz nakładów materiałowych związanych z procesem budowy świątyni (1 Krn 22, 5), a także przygotowując Salomonowi poparcie społeczne (1 Krn 22, 17nn) oraz kadrę specjalistów $(1 \mathrm{Krn} 22,15)$ dla tej monumentalnej inwestycji.

W osobie Salomona roztropność przejawiła się w takich działaniach, jak zorganizowanie administracji (1 Krl 4,1nn), ustanowienie nadzoru budowlanego (2 Krn 2,17c) oraz kierownictwa i organizacji placu budowy (1 Krl 5, 30; $2 \mathrm{Krn} 2,17 \mathrm{~b})$, staranie o niezbędnego kooperanta (1 Krl 5, 16-20) oraz wykwalifikowanych specjalistów (1 Krl 7, 13n; 2 Krn 2, 6). Ten władca-budowniczy nadał budowie świątyni rygor robót publicznych - co spowodowało rozłożenie wysiłku budowlanego zarówno na całą społeczność Izraela (1 Krl 5, 27), jak i na obcoplemieńców osiedlonych w jego królestwie (2 Krn 2, 16n). Wprowadził zmianowość zatrudnienia (1 Krl 5, 28), co zapobiegło przeciążeniu robotników. Zapewnił realizację właściwego harmonogramu, podejmując w pierwszej kolejności roboty o wydłużonym okresie realizacji ( 1 Krl 5, 22n. 31n; 2 Krn 2, 6-8). Cechy umysłu tego króla-budowniczego były tak wyjątkowe, iż stały się dla następnych pokoleń wzorem mądrości; „Salomonowa mądrość” znajduje się wśród biblicyzmów języka polskiego4.

\section{Solidność}

Ta cecha przejawia się w dążeniu przywódcy-budowniczego do uzyskania wysokich parametrów techniczno-budowlanych oraz walorów estetycznych (kunsztowny wystrój) wznoszonego sanktuarium.

Mojżesz wykazał solidność poprzez osobisty nadzór prac przy wznoszeniu Przybytku. Tekst biblijny (Wj 40,16-33) przypisuje temu przywódcy całokształt prac rzemieślniczo-budowlanych.Jest to jednak figura literacka zastosowana przez hagiografa, bowiem wykonanie tych czynności przez jednego człowieka nie jest możliwe nawet przy zaangażowaniu współczesnej techniki. Autor biblijny poprzez taką figurę

${ }^{4}$ Biblicyzmy języka polskiego podaje M. Wojciechowski, Biblical Phraseology in Polish and English, „The Polish Journal of Biblical Research” 4 (2004) nr 1 (7). 
literacką wyraża zwierzchnictwo, osobisty nadzór oraz głębokie zaangażowanie Mojżesza w całokształt prac przy wznoszeniu Przybytku.

Dawid wykazuje solidność, gromadząc znaczne środki w kruszcach oraz klejnotach (1 Krn29,2-5a), a także kosztowne wówczas surowce:brązi żelazo.

Cecha ta najwyższy wyraz osiągnęła w osobie Salomona, który zadbał zarówno o doskonałąjakość budulca ( $1 \mathrm{Krl} 5,24.31 ; 6,7 \mathrm{n})$, jak i niezwykłe bogactwo wystroju świątyni oraz jej otoczenia ( $1 \mathrm{Krl} 6,15-36$; 7, 15-22; $2 \mathrm{Krn} \mathrm{3,} \mathrm{4b-4,} \mathrm{9).} \mathrm{Przejawem} \mathrm{tej} \mathrm{cechy} \mathrm{są} \mathrm{również} \mathrm{starania} \mathrm{Salomona}$ o wykwalifikowaną kadrę budowlaną.

Solidność prac wykonywanych pod kierunkiem Zorobabela przy budowie Drugiej Świątyni wskazuje fragment raportu babilońskiego namiestnika Transeufratei: „Ta robota jest starannie wykonywana” (Ezd 5, 8c).

\section{Autorytet}

Na ten przymiot Mojżesza, budowniczego Przybytku, wskazuje wypełnienie przez Izraelitów (Wj 35, 21nn) jego nakazu dotyczącego daniny na cel budowy (Wj 35, 4-9). Na autorytet Dawida potwierdzają działania jego syna Salomona stanowiące realizację woli ojcowskiej (1 Krn 22, 6-16). Autorytet Salomona jako tytularnego budowniczego wskazuje informacja, iż to właśnie on ustalił wymiary świątyni do realizacji przez bezpośrednich wykonawców (2 Krn 3, 3). Narracja biblijna czyni również odniesienia do autorytetu Zorobabela (np. Ezd 3, 8c).

Istotny wpływ na uznanie przez społeczność autorytetu budowniczego sanktuarium Izraela wywarło wcześniejsze wyróżnienie go przez Boga poświadczone szczególnym zdarzeniem (w tym proroctwem): Mojżesza np. w Wj 14, 15n. 21; 34, 29, Dawida np. w 1 Sm 16, 1c. 12n; 1 Krn 11, 1nn, Salomona np. w 1 Krn 22, 8-11, Zorobabela np. w Za 4, 4nn. Autorytet przywódcy-budowniczego sanktuarium Izraela wiązał się również z jego pozycją społeczną: Mojżesza jako charyzmatycznego przywódcy religijnego, Dawida oraz Salomona jako obranych przez społeczność władców, Zorobabela jako osobistości o królewskim rodowodzie.

\section{Męstwo}

To cecha wspólna wszystkim starotestamentalnym przywódcom-budowniczym sanktuarium Izraela, szczególnie akcentowana w przy- 
padku osoby Mojżesza (np. Wj 2, 16n; 5, 1) oraz Dawida (np. 1 Sm 17, 22nn; 19, 8; 26, 7; $2 \mathrm{Sm} 8$, 1nn). Wykazuje ją również Zorobabel (Ezd 3, 3). Salomona do zachowania takiej postawy zachęca Dawid (1 Krn 22, 13c).

\section{Wnioski}

W wyniku dokonanej powyżej analizy narracji biblijnych podejmujących tematykę budowy starotestamentalnego sanktuarium Izraela, wskazano następujące okoliczności tej budowy:

- Bożą inspirację budowy,

- Boży wybór budowniczego 5 ,

- uprzedni status budowniczego jako przywódcy społeczności Izraela,

- walory osobowe przywódcy-budowniczego, które przynależą do kategorii cnót naturalnych oraz nadprzyrodzonych.

Wyeksponowanie tych okoliczności ujawnia jeden z fenomenów Bożego planu zbawienia.

Kraków

ANDRZEJ J. OBIDOWICZ

\section{Słowa kluczowe}

Stary Testament, natchnienie, przymioty, przywódca, budowniczy, budowa, sanktuarium, Izrael

\section{Summary}

The leader-builder of the Israel's sanctuary

according to the Old Testament narrative

Many books of the Old Testament deal with the theme of human building activity. Among Old Testament narratives it is possible to distinguish the special ones which present a special kind of activity undertaken as a result of divine inspiration addressed to the leader of the Israel community. This way the leader becomes the leader-builder of Israel's sanctuary (Herod the Great is omitted here because he is not mentioned in

${ }^{5}$ Sylwetkę pierwszego biblijnego wybrańca Bożego-budowniczego Noego przedstawiono w: A. Obidowicz, Potop w wersji biblijnej i pozabiblijnej. Porównanie biblijnego opisu potopu z literatura babilońska, praca magisterska napisana na seminarium z egzegezy biblijnej pod kierunkiem ks. dra hab. S. Hałasa SCJ, Kraków 2001 (mps w Archiwum Uniwersytetu Papieskiego Jana Pawła II). 
the text of the Old Testament). One can specify a few special attributes of the leaderbuilder of the sanctuary: the obedience and the trust in God, the piety, the prudence, the solicitude, the authority and the courage. The essential goal of the analysis in this paper is to expose those attributes.

\section{Keywords}

Old Testament, inspiration, attributes, leader, building, builder, sanctuary, Israel 